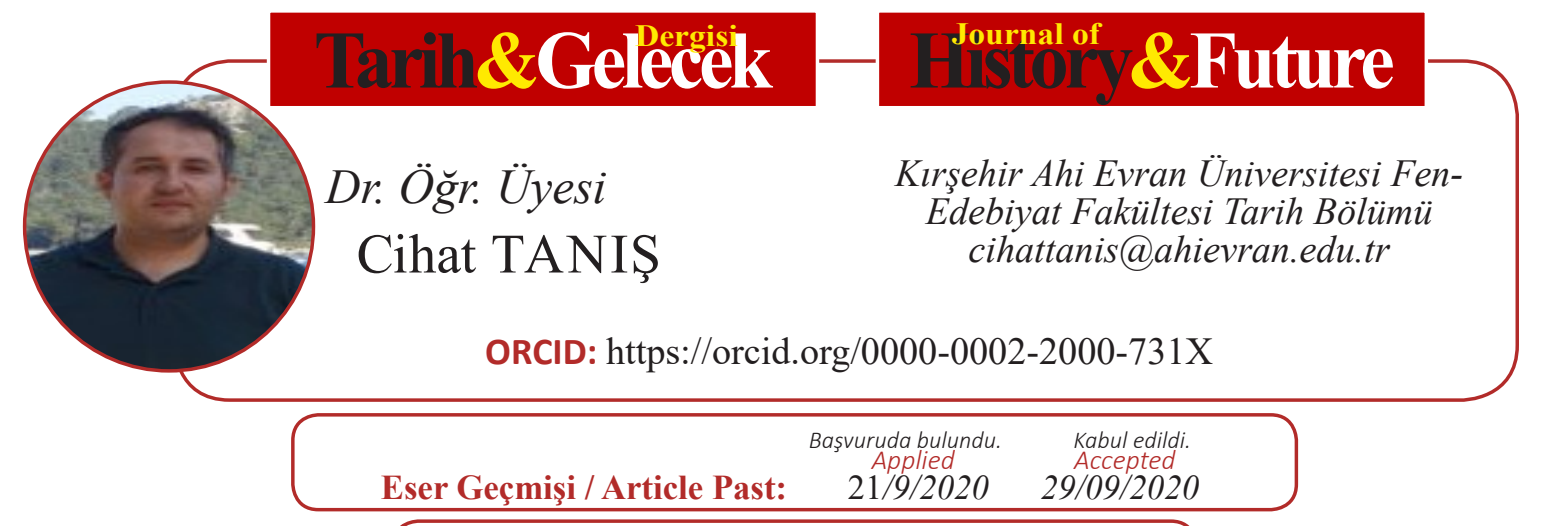

DOI: http://dx.doi.org/10.21551/jhf.798188

Research Paper

Orjinal Makale / Orginal Paper

\title{
Türk Milleti Ata'sıyla Vedalaşıyor: Anadolu'nun Bazı Kentlerinde Atatürk İçin Yapılan Matem Törenleri
}

\author{
The Turkish Nation Says Goodbye to his Ancestor: Mourning \\ Ceremonies Held for Atatürk in Some Cities of Anatolia
}

\section{Öz}

Türk Milleti’nin önderi Mustafa Kemal Atatürk yakalandığı amansız hastalık sonrasında 10 Kasım 1938 tarihinde hayata veda etmiştir. Bu elim olay gerek Türkiye'de gerekse yurt dışında büyük yankı uyandırmıştır. Özellikle Türk Milleti Ata'sının ansızın ölümü karşısında derin bir üzüntü yaşamıştır. Vefatından sonra Atatürk'ün naaşı İstanbul'da Dolmabahçe Sarayı'nda halkın ziyaretine açılmıştır. Daha sonra Hükümet, Atatürk'ün cenaze merasiminin 21 Kasım 1938 tarihinde Ankara da yapılması ve geçici istirahatgâhının Etnografya Müzesi olması kararını almıştır. CHP Genel Sekreterliği' nin ve Hükümetin hazırlamış olduğu cenaze merasimi programı tüm vilayetlere gönderilmiştir. Bu program sayesinde 21 Kasım günü yapılan törenler oldukça intizamlı, herhangi bir kargaşa yaşanmadan gerçekleştirilmiştir. Törenler belli bir program çerçevesinde tertip edilmelerinden kaynaklı benzerlik göstermiş olmalarına karşın içerik bakımından konuşmalar, okunan şiirler ve yaşanan duygusal anlar açısından farklılık arz etmiştir. Neticede hiçbir sıkıntının yaşanmadığı matem törenlerinde her yaştan, her meslekten binlerce insan katılmıştır. Böylelikle Türk Milleti önderine son görevini layıkıyla yerine getirmiştir.

Anahtar Kelimeler: Atatürk, Atatürk’ün Vefatı, Matem Töreni.

\begin{abstract}
The leader of the Turkish Nation, Mustafa Kemal Atatürk, died on 10 November 1938 after the relentless illness he caught. This sad event has aroused great repercussions both in Turkey and abroad. Especially, the Turkish Nation experienced a deep sadness in the face of the sudden death of its ancestor. After his death, Atatürk's body was opened for public visit at Dolmabahçe Palace in Istanbul. Later, the government decided that Atatürk's funeral would be held in Ankara on November 21, 1938, and that his temporary resting place would be An Ethnographic Museum. The funeral ceremony program prepared by the CHP General Secretariat and the Government has been sent to all provinces. Thanks to this program, the ceremonies held on November 21 were very organized, without any chaos. Although the ceremonies showed similarities due to the fact that they were organized within a certain program, they differed in terms of content, speeches, poems read and emotional moments experienced. As a result, thousands of people of all ages and professions participated in the mourning ceremonies, in which there were no problems. Thus, the Turkish nation has fulfilled its last duty to its leader properly.
\end{abstract}

Keywords: Atatürk, Death of Atatürk, The Mourning Ceremony.

ATIF: TANIŞ Cihat, "Türk Milleti Ata'sıyla Vedalaşıor: Anadolu'nun Bazı Kentlerinde Atatürk İçin Yapılan Matem Törenleri”, Tarih ve Gelecek Dergisi, 6/3 (Eylül 2020), s. (1051-1068)

CITE: TANIŞ Cihat, "The Turkish Nation Says Goodbye to his Ancestor: Mourning Ceremonies Held for Atatürk in Some Cities of Anatolia", Journal of History and Future, 6/3 (September 2020), pp. (1051-1068) 


\section{Giriş}

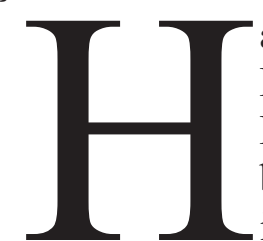

ayatının önemli bir bölümünü ülkesine adayan Atatürk, kurduğu Türk Devleti'ni her açıdan geliştirmek için büyük çaba göstermiştir. ${ }^{1}$ Mustafa Kemal Atatürk girdiği askerlik mesleğindeki üstün başarıları sayesinde iyi bir komutan olmuştur. İstiklal Savaşı'nda elde ettiği zaferle vatanı düşman işgalinden kurtarmıştır. Bunların karşılığı olarak Türk Milleti O’na Atatürk soyadını vermiştir. Nitekim Atatürk'ün, yaşadığı bu yoğun tempo zaman zaman onun bedenini yorgun ve zayıf düşürmüştür. ${ }^{2}$

Atatürk, bilindiği kadarıyla küçük yaşlarda sıtma hastalığının dışında herhangi ciddi bir hastalık geçirmemiştir. Gençliğinde sağlık bakımından sağlam bir yapıdadır. Trablusgarp Savaşı'nda gözünden, 1916 yılında Çanakkale Muharebeleri esnasında akciğerlerinden akabinde böbreklerinden rahatsızlanmıştır. Bu sebeple 1918 yılında doktorların önerisi ile Viyana'da tedavi görmüş ve oradaki kaplıcalarda dinlenmiştir. İstiklal Savaşı sürerken İstanbul'da Şile'de evinde bulunduğu sırada bir süre kulağı ağrımıştır. 1919 yılında Samsun'a çıktıktan sonra böbreklerinden yeniden rahatsızlanmış, Havza'daki kaplıcalarda kısa süre tedavi görmüştür. Sakarya Savaşı esnasında kaburga kemiğinin kırılması üzerine kısa bir süre tedavi görmüş ancak buna rağmen ordu karargâhından savaşı yönetmiştir. ${ }^{3} 1923$ 'te koroner spazm geçirmiş, 1927'de Nutuk'unu hazırladığ 1 sırada küçük bir rahatsılık geçirmiştir. ${ }^{4} 1923-1927$ yılları arasında kalp rahatsızlığı yaşamıştır. Ancak bu rahatsızlıkların neredeyse tamamı çok ağır olmayıp kısa sürede onun ayağa kalkmasına engel olmamıştır. Nitekim 1936 yılının Kasım ayında ciddi bir zatürre geçiren Atatürk’ün bedeni artık yavaş yavaş zayıflamaya başlamıştır. ${ }^{5}$

\section{A- Atatürk’ün Son Günleri ve Vefatı}

Yoğun çalışma hayatı 1937 yılından itibaren Atatürk'ün bedenindeki tahribatı geri dönülemez bir noktaya getirmiştir. Bu yıllarda burun kanamaları ve vücudunda aşırı bir kaşıntı oluşmuştur. ${ }^{6}$ Başka bir ifade ile Atatürk'ün askerî, siyasî, sosyal ve kültürel alanda gösterdiği olağanüstü gayret, onun bedenini yorgun düşürmüş ve 1937 yılı itibariyle çalışmalarını aksatacak ciddi bir hastalık meydana getirmiştir. Doktorları başlangıçta hastalığın ne olduğunu anlayamamışlardır. Atatürk'ün hastalığına ilk teşhisi Dr. Nihat Reşat Belger koymuştur. ${ }^{7}$ Belger, Yalova'da Termal Otel'de muayeneden sonra karaciğerin büyümesi ve sertleşmesinin hastalığa sebep olduğunu tespit etmiştir. Belger'e göre, Atatürk'ün hastalığı sirozdur. Diğer Türk ve yabancı doktorlar da Berger'in teşhisini onaylamışlardır. ${ }^{8}$ Böylelikle Atatürk'ün hastalığının siroz olduğu geç de olsa anlaşılmış ve tedavisi için perhizler konulmuştur. 1 Şubat 1938 'e kadar Yalova' da kalmıştır. ${ }^{9} \mathrm{Bu}$

Yansımaları", Akademik Tarih ve Düşünce Dergisi, 5/18, s. 96.

6 Üçüncü, s. 1187.

7 Nermin Zahide Aydın, (2019). "Mustafa Kemal Atatürk'ün Ölümü Üzerine Kilis Basınında Yer Alan Haberler”, Muallim Rufat Eğitim Fakültesi Dergisi, 1/1, s. 70.

8 Uğur Üçüncü, (2013). “Atatürk'ün Cenaze Merasimi Sırasında Türkiye'de Yapılan Matem Törenleri”, Türk Dünyası İncelemeleri Dergisi, 8/1, s. 80.

9 Üçüncü, s. 1188. 
süre içerisindeki tedavisi gayet faydalı sonuçlar doğurmuş; kaşıntıları azalmış, iştahı açılmıştır. Dr. Belger'in tedavinin üç hafta daha sürdürülmesi ısrarlarına rağmen Atatürk, 1 Şubat'ta Yalova'dan ayrılarak Bursa'ya gelmiştir. 3 Şubat günü öğleden sonra Bursa'dan Mudanya'ya, buradan da Ege Vapuru ile İstanbul'a gelmiş ve Dolmabahçe Sarayı'na geçmiştir. ${ }^{10}$

Yalova'dan sonra İstanbul'a varınca bu kez de zatürreye yakalanmıştır. Bu esnada devlet işlerini aksatmamış bir yandan yabancı devlet adamlarını karşılamış öte yandan Hatay meselesi ile yoğun bir şekilde ilgilenmiştir. Yoğun tempo hastalığını tekrardan artırmış bunun üzerine Fransa'dan Prof. Dr. Fisenger çağırılmıştır. Ayrıca 1938 yılının ilk günlerinden itibaren Fransa'ya ilaç siparişleri yapılmıştır. Bu arada az önce ifade edildiği üzere Hatay meselesinin siyasî bakımdan zorlu bir süreçten geçiyor olması üzerine doktorların karşı çıkmalarına rağmen, Atatürk Mersin ve Adana seyahatlerine çıkmıştır. Bu seyahat ona yaramamış ve rahatsızlığı iyice ilerlemiştir. İstanbul'a varınca İstanbul Savarona yatında dinlenmeye ve tedaviye alınmıştır. ${ }^{11}$ Yattaki yaşam da iyi gelmeyince 25 Temmuz'dan itibaren Dolmabahçe Sarayı'nda tedaviye devam edilmiştir. Tedaviler devam ederken, Atatürk'ün hastalığı halk arasında duyulmuştur. Bu haber üzerine Türk Milleti Atatürk’ün hastalığını yakından takip etmiştir ${ }^{12}$

Atatürk’ün sağlık durumuyla ilgili gelişmeler Cumhurbaşkanı Genel Sekreteri Hasan Rıza Soyak tarafından düzenli bir şekilde Başbakanlığa bildirilmiştir. ${ }^{13}$ Hükümet ise durumu basın aracılığıyla Türk kamuoyu ile paylaşmıştır. Nitekim Atatürk, sağlığının kısmen iyi olduğu günlerde devlet meseleleri ile ilgilenmeyi ihmal etmemiştir. Örneğin, Kayseri Belediye seçimlerini yakından izlemiştir. Bu esnada Cumhuriyet'in 15. Yıldönümü kutlamaları ve TBMM'nin açılış merasimi yaklaşmıştır. Atatürk Ankara'daki törenlere gitmeyi çok arzulamıştır. Fakat gerek doktorların gitmemesi yönündeki tavsiyesi gerekse hastalığın ağır seyretmesi bunu engellemiştir. Bu nedenle ilk kez Cumhuriyet Bayramı ve Meclis' in açılış törenleri Atatürk olmadan yapılmıştır. O'nun adına Başbakan Celal Bayar bir açış konuşmasını yapmıştır. ${ }^{14}$

$\mathrm{Bu}$ esnada siroz hastalığı nedeniyle Atatürk'ün karnı su topluyordu. Doktorlar, yaptıkları ponksiyonlarla Atatürk'ün karnından birkaç kez su almışlardır. Atatürk operasyonların tehlikeli olacağı kanaatiyle vasiyetnamesini yazdırmıştır. ${ }^{15}$ İkinci ponksiyon, 22 Eylül'de yapılmış ve 12 litre su alınmıştır. Atatürk yapılan ponksiyonlar sonrasında rahatlamaktaydı. Ancak karın bölgesi kısa süre içinde yeniden su toplamıştır. Atatürk'ün sağlık durumu 8 Kasım akşamı saat 18:30'dan itibaren kötüleşmiştir. Ağırlaşan hastalığ1 gazeteler ve radyo vasıtasıyla Hükümet'in hazırladığ 1 bir tebliğle halka duyurulmuştur. Doktorlar Atatürk'ün başucundan ayrılmamaya başlamıştır. ${ }^{16}$ Nitekim bütün çabalara rağmen Türk Milleti'nin Ata's1 10 Kasım günü saat 09:05'te hayata veda etmiştir. Ata'nın vefatı Türk basınında geniş bir şekilde yankılanmıştır. ${ }^{17}$ 20. yüzyıla damgasını vuran en büyük liderlerden biri olan Atatürk'ün ölümü Türk halkını derinden üzmüştür. Bunun

10 İbrahim Çakır, (2007). Atatürk'ün Ölümünün Türk Basınındaki Yankıları, Niğde Sosyal Bilimler Enstitüsü (Yayınlanmamış Yüksek Lisans Tezi), Niğde, s. 58-59.

11 Kodal, s. 18

12 Haykır, s. 531.

13 BCA, 30.10.0.0.1.4.3; BCA, 30.10.0.0.1.4.5; BCA, 30.10.0.0.1.4.6; BCA, 30.10.0.0.1.4.7; BCA, 30.10.0.0.1.4.8; BCA, 30.10.0.0.1.4.9;

14 Konuşmanın tam metni için bkz. T.C. Resmî Gazete, 2 Kasım 1938, S. 4052, s. 10815-10817.

15 BCA, 30.10.0.0.0.808.1.

16 Üçüncü, s. 1190-1192.

17 Akşam, 10 Kasım 1938, nr. 7210, s. 1; Anadolu, 11 Kasım 1938, nr. 7679, s. 1; Aydın, 11 Kasım 1938, nr. 389, s. 1; Cumhuriyet, 10 Kasim 1938, nr. 5208, s. 1; Son Posta, 10 Kasim 1938, nr. 2976, s. 1; Tan, 11 Kasim 1938, nr. 1180, s. 1; Ulus, 10 Kasim 1938, s. 1. 
yanı sıra onun ölümü yurt dışında da büyük yankı uyandırmıştır. ${ }^{18}$ Birçok ülkenin elçiliği Dışişleri Bakanlığını ziyaret ederek taziyede bulunmuşlardır. ${ }^{19}$ Ayrıca üniversite öğrencileri Atatürk için toplanmışlar ve ant içip onu yad etmişlerdir. ${ }^{20}$

\section{B- Atatürk’ün Cenaze Töreni Hazırlıkları ve Ankara'da Yapılan Tören}

10 Kasım günü Atatürk'ün vefatı önce İstanbullular tarafından öğrenilmiş ardından acı haber hızla tüm Türkiye'ye yayılmıştır. ${ }^{21}$ Haberin ardından İstanbul'da sinemalar, tiyatrolar ve her türlü eğlence yerleri kapanmış, birçok dükkân ya kepenklerini indirmiş ya da tamamen kapatmıştır. İstanbul ahalisi sokakları, Ata'sı için doldurmuştur. Birçok okulda öğleden sonra ders yapılmamış, öğretmenler öğrencilerini teskin etmeye çalışmışlardır. Anadolu'da halk gözyaşları içinde Atatürk anıtları önünde toplanmış ve radyodan yapılacak açıklamaları beklemiştir. Ayrıca kamu kurumlarında bayraklar yarıya indirilmiştir. Türkiye' deki yabancı elçilikler de bayraklarını yarıya indirerek Türkiye'nin millî matemine katılmışlardır. ${ }^{22}$

Atatürk'ün naaşı 11 Kasım'da defin işleri için hazırlanmıştır. İlk olarak tahnit işlemi yapılmıştır. Tahnitten sonra vücut tabut içine konmuştur. Ardından 14 Kasım 1938 günü Dolmabahçe Sarayı Merasim Salonundaki katafalka konulmuştur. ${ }^{23}$ Burada İstanbul halkının Ata'sını ziyaret etmesi sağlanmıştır. ${ }^{24}$

15 Kasım 1938'de Atatürk'ün cenaze töreninde yapılacak masrafların karşılanması amacıyla dönemin parasıyla 500 bin TL tutarında bir meblağ belirlenmiştir. ${ }^{25} \mathrm{Bu}$ arada tüm Türkiye'de bir ay süre ile yas ilan edilmiştir. ${ }^{26}$ Cenaze töreninin ise 21 Kasım Pazartesi Ankara'da yapılması kararlaştırılmıştır. Ankara'daki Cenaze töreni ve yurdun diğer vilayetlerinde yapılacak olan matem törenlerinin nasıl organize edileceği ile ilgili hükümet tarafından bir kararname çıkarılmıştır. ${ }^{27} \mathrm{Bu}$ kısa kararnameye ek olarak CHP Genel Sekreterliği tarafindan bir de genelge yayınlanmış ve tüm vilayetlere gönderilmiştir. ${ }^{28}$ Buna göre, 15.11 .1938 tarihli ve 1310 sayılı genelge ile;

1- Ankara'da 21 Kasım Pazartesi günü saat 11:00'da yapılacak olan cenaze merasiminin yanı sıra diğer şehirlerin Halkevlerinde de bir tören organize edilecek ve törenler İstiklal Marşı ile açılarak Atatürk'ün hayatı hakkında yapılacak bir konuşmadan sonra gençliğe hitabı okunacak ve üç dakika saygı duruşu ile törene son verilecektir. Aynı gün saat 14:00'da başlayacak törende Halkevi bulunan yerlerde üyelerden bir kişi gönderilen genelgeye uygun konuşma yapacaktır.

2- 22 Kasım tarihi olan Salı gününden itibaren halkevleri normal faaliyetlerine geri

18 Ramazan Çalık (2002). “Atatürk'ün Vefatı ve Alman Basını”, Atatürk Araştırma Merkezi Dergisi, 18/54, s.885; Akşam, 13 Kasım 1938, nr. 7213, s. 2; Anadolu, 13 Kasım 1938, nr. 7681, s. 1; Cumhuriyet, 14 Kasım 1938, nr. 5212 , s. 5.

19 Akşam, 11 Kasım 1938, nr. 7211, s. 2; Cumhuriyet, 13 Kasım 1938, nr. 5211, s. 1; Tan, 12 Kasım 1938, nr. 1181 , s. 9.

20 Cumhuriyet, 14 Kasim 1938, nr. 5212, s. 5; Tan, 14 Kasim 1938, nr. 1183, s. 1.

21 Akşam, 10 Kasım 1938, nr. 7210, s. 1.

22 Anadolu, 18 Kasım 1938, nr. 7686, s. 3; Cengiz Akseki, (2016). “Atatürk’ün Ölümünün Türk Ulusal Basınına Yansımas1 (1938-1939)", BELGI, 12, s. 202-203.

23 Tunç Boran, (2011). “Atatürk’ün Cenaze Töreni: Yas ve Metanet”, Ankara Üniversitesi Türk Inkılâp Tarihi Enstitüsü Atatürk Yolu Dergisi, 7, s. 491.

24 Son Telgraf, 16 Kasım 1938, nr. 610, s. 1; Akşam, 16 Kasım 1938, nr. 7216, s. 1; Anadolu, 19 Kasım 1938, nr.7687, s. 1.

25 Akşam, 15 Kasım 1938, nr. 7215, s. 1, 5; Anadolu, 15 Kasım 1938, nr. 7683, s. 1; Cumhuriyet, 15 Kasım 1938 , nr. 5213 , s. 1.

26 Alev Özbil, (2012). “Türkiye Cumhurbaşkanlarının Cenaze Merasimleri”, Yakın Dönem Türkiye Araştırmaları, 11/22, s. 27-29.

27 Akşam, 15 Kasim 1938, nr. 7215, s. 7; Akşam, 16 Kasım 1938, nr. 7216, s. 4.

28 Akşam, 16 Kasım 1938, nr. 7216, s. 2. 
dönecektir. Ancak Atatürk'ün vefatı olan 10 Kasım 1938 tarihinden itibaren bir ay zarfinda Halkevlerinde balo, ziyafet, çaylı dans gibi toplantılar yapılmayacak, CHP ve Halkevi mensupları bu müddet içinde akşam yemeklerine icap etmeyeceklerdir. ${ }^{29}$

3- Halk saat 14:00'da heykel ve büst olan yerlerde bunların etrafinda, olmayan yerlerde ise Cumhuriyet meydanlarında toplanacaktır.

4- Heykel ve büst bulunmayan meydanlarda büyük bir kürsü üzerine Atatürk’ün fotoğrafı konacaktır. Kürsü Türk ve CHP bayrakları ile örtülecek başka hiçbir siyasi işaret bulunmayacaktır.

5- Toplanma intizamlı bir şekilde düzenlenecektir. Bunun için bir komisyon toplanacak ve kroki hazırlayacaktır.

6- Atatürk'ün emanet ettiği Türk Gençliği en ön safta yerini alacaktır.

7- Bando Chopin ve Beethoven'un matem marşlarını çalabilecektir. Bu marşların çalınamadığı yerlerde sadece İstiklal Marşı çalınacaktır. Bando olmayan yerlerde ise İstiklal Marşı ağızdan söylenerek törene başlanacaktır.

8- Tören bu şekilde açıldıktan sonra her yerde üç konuşma yapılacaktır. Bunları CHP temsilcisi, belediyelerden bir kişi, belediye olmayan yerlerde köy ihtiyar heyeti üyelerinden biri ve halktan bir genç yapacaktır. Konuşmalar ant içilerek bitirilecektir.

9- Tam saat 16:00'da genelgeye göre üç dakikalık saygı duruşuna geçilecektir.

10- Saygı duruşunun ardından altı meşale ateşlenecek ve Atatürk büstü veyahut heykeli önünden saygı geçidi yapılarak törene son verilecektir.

11- Toplanma meydanına gelirken isteyenler Atatürk büstüne çelenk veya çiçek koyabilirler.

12- Yapılan merasimler mümkün olduğunca fotoğraflanıp CHP Genel Merkezi’ne gönderilecektir. ${ }^{30}$

Yukarıda belirlenen talimatlar doğrultusunda 21 Kasım'da bütün ülkede resmi dairelerin ve okulların, eğlence yerlerinin kapanması, cenaze gününün ertesi gününe kadar bayrakların yarıya indirilmesi, cenaze töreninin yapılacağ 1 gün il ve ilçe merkezlerinde Atatürk'ün anısına tören yapılmasına karar verilmiştir. $21 \mathrm{Kasım} \mathrm{günü} \mathrm{Ankara} \mathrm{dışındaki} \mathrm{bütün} \mathrm{illerde} \mathrm{yapılacak} \mathrm{törenlerde}$ uyulacak esaslar ile Halkevlerinde yapılacak törenlerin şekli belirlenmiş, 10 Kasım'dan itibaren bir ay süre ile devlet memurlarının, CHP ile halkevi üyelerinin verilecek akşam yemeklerine katılmamaları ve kendilerinin de davet vermemeleri kararlaştırılmıştır. ${ }^{31}$

Atatürk'ün naaşının İstanbul'dan Ankara'ya nakli ve Ankara'daki törenle ilgili olarak oldukça ayrıntılı bir program hazırlanmıştır. Programda, İstanbul'da yapılacak törenden, naaşın nereden, nasıl ve ne şekilde alınacağı, törende giyilecek kıyafetlerden, kimin nerede ve nasıl duracağına, Atatürk'ün naaşının geçeceği güzergâhlar ve güzergâhlarda neler yapılacağının belirlenmesine

30 BCA, 490.1.0.0.4.19.15, Lef 1-5; Tan, 16 Kasim 1938, nr. 1185, s. 3.

31 Ulus, 13 Kasım 1938, s.1; Anadolu, 17 Kasım 1938, nr. 7685, s. 3, 6; Özbil, s. 27-29. 
kadar her türlü ayrıntı düşünülmüştür. ${ }^{32}$ Buna göre, Cenaze 20 Kasım'da trenle İstanbul'dan Ankara'ya getirilecek, istasyondan Etnografya Müzesi'ne götürülecek ve kalıcı kabri inşa edilene kadar orada kalmasına karar kılınmıştır. ${ }^{33}$ Atatürk'ün cenazesine vatandaşların Dolmabahçe Muayede Salonu'nda 16-18 Kasım 1938 tarihleri arasında üç gün süreyle saygı sunmasının ardından harp gemilerinin refakatinde Yavuz Zırhlısıyla İstanbul'dan İzmit'e nakledilmiş, buradan da trenle Ankara'ya ulaşmıştır. ${ }^{34}$

Ankara'daki cenaze töreni çok büyük bir kalabalık eşliğinde gerçekleşmiştir. Törene birçok ülkeyi temsil eden diplomatlar katılmıştır. Gerçekleşen törenin ardından saat 10:45'te cenaze korteji, meclisin önünden Etnografya Müzesi'ne Cumhurbaşkanlığı Bandosu'nun çaldığı Chopin'in matem marşı eşliğinde hareket etmiştir. Cenaze kortejinin önünde Türk ve yabanc1 askerî birlikler ve bandolar yer almıştır. Askeri birliklerin ardında 80 askerin çektiği ve yanında kılıçlarını çekmiş 12 generalin bulunduğu Atatürk'ün tabutunu taşıyan top arabası ilerlemiştir. ${ }^{35}$ Top arabasını Atatürk'ün İstiklal Madalyası'nı taşıyan bir general takip etmiştir. Hemen ardından kız kardeşi Makbule Hanım ve eşi yürümüştür. Cumhurbaşkanlığ 1 Genel Sekreteri Hasan Rıza Soyak ve Atatürk'ün yaverlerinin arkasında Cumhurbaşkanı İnönü, ağır adımlarla ilerlemiştir. Cumhurbaşkanı'nın ardından Türkiye Büyük Millet Meclisi Başkanı Abdülhalik Renda, Başbakan Celal Bayar, Genelkurmay Başkanı Fevzi Çakmak yer almıştır. Kortejde, daha sonra sırasıyla bakanlar, milletvekilleri, askerî ve mülkî erkân bulunuyordu. Ayrıca büyükelçiler ve yabancı temsilciler de yerlerini almışlardır. ${ }^{36}$ Cenaze kortejinin güzergâhında bulunan Gençlik Parkı'nı ise halk doldurmuştur. Kortej, saat 13:10'da Etnografya Müzesi'ne ulaşmıştır. Devlet adamlarının ve korteje katılanların veda geçişi ile tören son bulmuştur. ${ }^{37}$ Aynı gün Türkiye' nin bütün vilayetlerinde de matem töreni düzenlenmiştir. ${ }^{38}$

\section{C- Bazı Vilayetlerde Yapılan Matem Törenleri}

21 Kasım 1938 Pazartesi günü Ankara' da ve diğer illerde düzenlenecek tören ile ilgili olarak Cumhuriyet Halk Partisi Genel Sekreterliği parti teşkilatlarına 15 Kasım 1938 günü bir genelge yayınlanmıştır. Yukarıda belirtilen bu genelge ile heykel ve büstlerin ne şekilde süsleneceğinden, söylenecek nutuklara, marşlara ve hatta çiçeklere kadar törende yapılması gereken hususlar ayrıntılı bir şekilde belirlenmiştir. Hükümet de aynı gün cenaze töreni ile ilgili kararname göndermiştir. Hükümetin kararnamesi, Cumhuriyet Halk Partisi Genel Sekreterliği'nin genelgesine göre daha kısadır. ${ }^{39}$ Verilen bu talimatlar doğrultusunda Türkiye'deki tüm vilayetler canla başla tören için hazırlıklarını yapmışlardır. Vilayetlerde gösterilen bu yoğun gayretler sonucunda Atatürk'ün matem töreni büyük katılımların sağlanmasıyla sorunsuz şekilde gerçekleşmiştir. Bu şekilde planlanan ve büyük kalabalıkların katılımıyla gerçekleşen matem törenleri birçok ilde bazı ufak farklılıklar dışında neredeyse aynı düzende gerçekleştirilmiştir. Buna göre;

32 Uzun, s. 534.

33 Akşam, 15 Kasım 1938, nr. 7215, s. 1; Anadolu, 15 Kasım 1938, nr. 7683, s. 3; Anadolu, 17 Kasım 1938, nr. 7685 , s. 3.

34 Cumhuriyet, 19 Kasım 1938, nr. 5217, s. 5; Akşam, 20 Kasım 1938, nr. 7220, s. 1-2; Anadolu, 20 Kasım 1938, nr. 7688, s. 1; Figen Atabey, (2012). “Atatürk Denizden Yapılan Cenaze Töreni”, Atatürk Araştırma Merkezi Dergisi, 28/83, s. 20; Haykır, s. 531; Uzun, s. 533.

35 Ulus, 22 Kasim 1938, s. 1.

36 Akşam, 22 Kasım 1938, nr. 7222, s. 2; Anadolu, 15 Kasım 1938, nr. 7683, s. 3.

37 Akşam, 22 Kasım 1938, nr. 7222, s. 2; Cumhuriyet, 22 Kasım 1938, nr. 5220, s. 7; Boran, s. 513-514.

38 Akşam, 21 Kasım 1938, nr. 7221, s. 3.

39 Boran, s. 496. 


\section{1- Aydın:}

Atatürk'ün vefatının ardından yurt genelinde yapılacak matem törenleri hiç şüphesiz halkın yoğun katılımıyla gerçekleştirilmiştir. Yukarıda da ifade edildiği üzere belli bir program dahilinde gerçekleştirilen bu törenler hüznün ve duygu yoğunlukların yaşanmasına sebep olmuştur. Aydın ilinde 21 Kasım 1938 tarihinde gerçekleştirilen törende bütün esnaf iş yerlerini kapatmıştır. Yalnızca firın, lokanta, kasap ve manavlar saat 13'ten 17'ye kadar açık kalmıştır. Bütün halk saat 11:00'dan itibaren Halkevi'nde toplanmaya başlamıştır. Burada yapılan törenin ardından nerdeyse tüm Aydın halkı Cumhuriyet alanında toplanmıştır. Tören esnasında kimsenin siyah renkte bir eşya taşımasına izin verilmemiştir. Saatler 13:45'i gösterdiğinde bütün vatandaşlar tören komitesinin göstermiş olduğu yerde hazır olmuşlardır. Tören başlamadan önce Atatürk büstüne çelenk konulmuştur. ${ }^{40}$ Törene saat 14:00' da Halkevi bandosunun çaldığı İstiklal Marşı ile başlanmıştır. ${ }^{41}$ Akabinde Halkevi bandosu matem marşı çalmıştır. Marşlar bittikten sonra CHP İl Başkanı Osman Bozkurt kürsüye çıkıp bir konuşma yapmıştır. Konuşmasına "Atatürk evlatlarl... Vatan aşkı ile çarpan kalpler kimsesiz kalan vatanı kurtarmak için bir halaskâr arıyordu... İşte o gün vatan büyük halaskârı milletin gözbebeği, dünyanın saydığı Atatürk Samsun'da atını şaha kaldırıp millete istiklal müjdesini vermişti..." sözleriyle başlamıştır. Konuşmasının devamında Atatürk’ün Türk Milleti'ne yaptığı sayısız hizmetlerden bahsetmiş ve ant içerek sözlerine son vermiştir. ${ }^{42}$ Akabinde halkın birçok kesiminden konuşmalar yapıldıktan sonra saat 16:00'da üç dakikalık saygı duruşu yapılmış ve ardından Atatürk büstünün önünden geçit yapılarak törene son verilmiştir. Matem merasimi Aydın'ın ilçelerinde de yapılmıştır. Buralarda yapılan törenler de en az il merkezi kadar kalabalık bir şekilde ve Atatürk için yazılan şiirlerin okunmasıyla gerçekleşmiştir. Mesela Söke'de Ata’sı için;

“Toprak kıyarak en büyük evladını aldı.

Türk Milleti sonsuz, acı bir mateme daldı.

Kaplar koca bir kürreyi bir anda şeamet.

Milyonları aştı duyulan ahu felaket."

Dörtlüğü ile başlayan bir şiiri kaleme alan vatandaş bunu kürsüden tüm Sökelilere okumuştur. ${ }^{43}$ Aydın basınına yansıdığı kadarıyla katılım o kadar fazla olmuştur ki sokaklar, meydanlar vatandaşlar tarafından doldurulmuştur. Atatürk büstü önüne koyulan çelenklerin sayısı da çok fazladır. Yine basına yansıdığı kadarıyla bu çelenkleri ancak bir kamyon götürebilirdi. ${ }^{44}$

\section{2- Bitlis:}

21 Kasım günü Bitlis’teki tüm resmi daireler ve dükkanlara varıncaya kadar bütün iş yerleri Ata’sını anmak için kapatılmıştır. İlk olarak öğrenciler, subaylar, memurlar ve halk Halkevi'nde saat 11:00'da Atatürk'ün hayatı hakkında verilen nutku dinlemişlerdir. Buradaki törenin ardından vatandaşlar Atatürk büstünün bulunduğu Cumhuriyet alanında tanzim edilen krokiye göre yerlerini

40 BCA, 490.1.0.0.1429.724.1, Lef 4.

41 Aydın, 22 Kasim 1938, nr. 398, s. 2.

42 BCA, 490.1.0.0.1429.724.1, Lef 9-10.

43 BCA, 490.1.0.0.1429.724.1, Lef 38.

44 Aydın, 22 Kasim 1938, nr. 398, s. 1-2. 
almışlardır. Atatürk büstü Türk bayrakları ile sarılmış ve büstün etrafına altı meşale yerleştirilmiştir. Tören esnasında vilayetteki okullar, devlet kurumları ve Halkevi tarafından çelenkler konulmuştur. Saat 14:00'da İstiklal Marşı ile başlayarak saat 17:00'a kadar devam eden törende Atatürk'ün hayatı ve ölümünden doğan milli acı hakkındaki konuşmalar büyük bir hüzünle dinlenmiştir. Töreninin sonuna doğru programın sunucusu Atatürk için yapılan andı okumuş halk da tekrar etmiştir. Söylevlerin bitiminin ardından Belediye tarafından atılan işaret topu ile altı meşale birden ateşlenmiş ve Atatürk'ün aziz hatırası için üç dakika saygı duruşu yapılmıştır. Akabinde büstün önünden geçit yapılarak törene son verilmiştir. ${ }^{45}$

\section{3- Bolu:}

Bolu'da törenin yapıldığı gün olan 21 Kasım'da bütün kurumlar kapanmıştır. Yanı sıra dükkân ve mağaza sahipleri de Ata'ya saygı için iş yerlerini kapatmışlardır. Matem töreni için köy ve kasabalardan şehir merkezi sabahın erken saatlerinden itibaren çok sayıda vatandaş gelmiştir. Vatandaşlar hüzün içinde Cumhuriyet Meydanı gibi şehrin önemli merkezlerine yerleştirilen hoparlörlerden Atatürk için Ankara'da gerçekleştirilen cenaze merasimini takip etmeye başlamışlardır. Saat 11:00'da Halkevi'nde Atatürk'ün hayatı, göstermiş olduğu başarılar ve yaptığı inkılaplar anlatılmıştır. Konuşma esnasında Atatürk'ün Türk Gençliğine Hitabesi ve şiirler okunmuştur. Halkevindeki program sonlandıktan sonra saat 14:00'da Atatürk büstünün önünde toplanılmıştır. Bolu'da matem törenine her yaştan binlerce kişi katılım sağlamıştır. Tören tam saat 14:00'da İstiklal Marş1 ile başlamıştır. İlk olarak bütün kurum ve cemiyetler büstün önüne çelenklerini koymuşlardır. Akabinde birçok kişi kürsüye çıkarak Atatürk ile ilgili hüzünlü konuşmalar yapmışlardır. Konuşmalar ant içildikten sonra son bulmuştur. Saat 16:00'da tüm şehir üç dakikalık saygı duruşuna geçmiştir. Saygı duruşunun ardından büstün önündeki altı meşale yakılmış ve öğrenciler, subaylar, memurlar geçit yaptıktan sonra tören sona ermiştir. ${ }^{46}$

\section{4- Çanakkale:}

Çanakkale'de matem töreninin saat 11:00'da başlayacağı önceden halka duyurulmuştur. $\mathrm{Bu}$ nedenle vatandaşlar Halkevindeki yerlerini saatlerden öncesinden almaya başlamışlardır. $\mathrm{Bu}$ bağlamda tam saat 11:00'da İstiklal Marşı ile Halkevi'ndeki törene başlanmıştır. Akabinde Halkevi üyesi bir kişi Atatürk ile ilgili konuşma yapmış ve ardında Gençliğe Hitabe okunmuş ve sonunda üç dakika saygı duruşuna geçilmiştir. Son olarak ise bando tarafından Chopin'in matem marşı çalınmıştır. 21 Kasım günü esnaf kendi arzusuyla dükkanlarını kapatıp törene iştirak etmiştir. Saat 14:00'da bütün halk Cumhuriyet Meydanı'nı doldurmuştur. Tören İstiklal Marşı ile açılmış akabinde Halkevi Başkanı Halil Dilmaç ve üyeler konuşmalar yapmışlar ve ant içilmiştir. ${ }^{47}$ Saat 16:00'da ise atılan top ile Atatürk'ün aziz hatırası için üç dakikalık saygı duruşu yapılmış ve Atatürk anıtının etrafındaki meşaleler yakılmıştır. Çanakkale'de törene ilgi o kadar büyüktür ki, sadece büst önüne konan çelenk sayısı 100'ün üzerinde olmuştur. Tören subaylar, öğrenciler, memurlar ve vatandaşların Atatürk anıtı önünden geçmesi ile son bulmuştur. ${ }^{48}$

\section{5- Ordu:}

Ordu’ da düzenlenecek matem töreni için Cumhuriyet Alanında yer alan Atatürk büstü önüne Ata'nın fotoğrafi konulmuş ve kürsü Türk ve CHP bayrakları ile örtülmüştür. Vilayetteki bütün kurumlar saat 14:00'da çelenklerini fotoğrafın önüne koymuşlardır. Katılımın çok fazla olması

BCA, 490.1.0.0.1429.725.1.36, Lef 36-37.

BCA, 490.1.0.0.1429.725.1.1, Lef 1-2.

48 BCA, 490.1.0.0.1429.725.1, Lef 21. 
sebebiyle vatandaşlar önceden Valilik nezdinde oluşturulan tören komisyonunca çizilen krokiye göre yerlerine geçmişlerdir. Saat 14:00'da tören bandonun İstiklal Marşı'nı çalmasıyla başlamıştır. Konuşmalar sonlandıktan sonra elektrik santral düdüğünün verdiği işaretle Ordulular üç dakikalık saygı duruşu yapmış ardından altı oku temsilen altı meşale ateşlenmiştir. Daha sonra Türk gençliği, onu takiben memurlar ve halk olmak üzere Atatürk'ün fotoğrafı önünden bir ihtiram geçidi yapmak suretiyle törene son verilmiştir. Törenin bitiminden sonra kürsü ve fotoğraflar bozulmamış ve yakılan meşaleler ertesi günü saat 12 'ye kadar söndürülmemiştir. ${ }^{49}$

Tören esnasında CHP adına Diş Hekimi Yekta Karamustafa, şehir adına Ortaokul öğretmeni Sıtkı Can, halk adına Gürses Gazetesi sahibi Ali Rıza Gürsoy ve Halkevi adına ise Cumhuriyet Okulu Ahmet Hamdi tarafından söylevler yapılmıştır. Bu nutuklarda Atatürk'ün eserleri, memleket ve millete yaptığı büyük hizmetler, hayatı ve aramızdan ayrılması ile duyulan yeis tebarüz ettirilmiş ve en sonunda Atatürk ve Cumhuriyet sevgisinin en yüksek seviyede olduğu ve bu sevgiye daima daha fazla koşulacağı hakkında hep bir ağızdan ant içilmiştir. Anlaşılacağı üzere Ordu'da yapılan merasim resmî törenlerin sadeliğinin ötesinde konuşmacıların muazzam şiirleri ve nutukları okumasıyla başka bir anlam kazanmıştır. Bu eserlerden bir tanesi Diş Hekimi Yekta Karamustafa tarafindan söylenilen Ecel Utansin adlı şiirdir;

"On ikinci teşrin rüzgâra sordum Atam hasta, fakat ölmez diyordum. Dedi: Atan öldü inanmiyordum. Eyvah olan olmuş ecel utansin.

On yedi milyonun kanlı yaşları Sel gibi akarken ecel utansin Yanık bağırları, bükük başları, Görsün de o namert ecel utansin.

Yas zehrini içtik biz damla damla, Gündüzün fark yok şimdi akşamla, Tan yeri kararmış matemle kanla, Bir Türklük ağllyor ecel utansin.

Elemle sararmış benizler uçuk, Hicranla çağllyor hep çoluk çocuk, Ruhlarda yangin var yürekler buruk, Bir Türklük ağllyor ecel utansin.

Gönüller acılı gözler bulanık, On yedi milyonun kalpleri yanı, Boğazlar kurumuş nefes tıkanı, Bir Türklük ağllyor ecel utansin.

Mavi gök çatlasin, ylldırım insin, Ulu Türk geliyor Tanrt sevinsin, Cihan yas bağlasın, kara giyinsin, Bir Türklük ağllyor ecel utansin ... 
... Sen ölmedin ATAM kalplerde yerin, Cihan durdukça var büyük eserin, Manevi varlı̆̆ın Nuru Türklerin, Türklük ebedîdir ecel utansin..."

Şiir çok uzun olmakla beraber ancak bir kısmına burada yer verilmiştir. Ardından Türkçe Öğretmeni Sıtkı Can bir konuşma yapmış ve o da bir şiir okumuştur. Konuşmasında Atatürk’ten övgü dolu sözlerle bahseden Sıtkı Bey A tatürk'ün Türk Milleti nezdindeki önemine vurgu yapmıştır. Akabinde;

"Canindan can verirdi sorsa idin her Türk'e, Nasıl kiydin Allah'ım başımız Atatürk'e, O, Türklük kalbinde yaşayan heyecandl, Ölen Atatürk değil, ylkilan bir cihandl..."

Dörtlüğüyle başlayan şiiri okumuş ve konuşmasını sonlandırmıştır. Sıtkı Bey'in ardından kürsüye Cumhuriyet Okulu Baş Öğretmeni Ahmet Hamdi Bey geçmiş ve bir konuşma da o yapmıştır. Konuşmaların ardından benzer şekilde hüzün dolu içeriklere sahip şehrin önde gelen birçok kimsesi konuşma yapmıştır. ${ }^{50} \mathrm{Bu}$ şekilde tören son bulmuştur.

\section{6- Niğde/Bor:}

Ulusun içinde bulunduğu bu matem günü tüm yurtta olduğu gibi Niğde'nin Bor ilçesinde de büyük bir katılım ve hüzün ile gerçekleştirilmiştir. Bor'daki program 21 Kasım günü saat 11:45'te Halkevinde yapılan konuşmalar ile başlamıştır. Akabinde saat 14 sularında Cumhuriyet Meydanı'nda vatandaşlar, öğrenciler, sivil ve askeri bürokrasi daha önceden belirlenen yerlerini almışlardır. Tören başlamadan önce bütün kurumlar Atatürk büstü önüne çelenklerini koymuşlardır. Hazırlıklar tamamlandıktan sonra bandonun İstiklal Marşı'nı çalması ile tören resmen başlamıştır. İstiklal Marşı'nın bitiminden sonra Belediye namına İzzet Can, Halk adına Hasan Turgut ve CHP adına ise Fuat Mengi Beyler tarafından birer konuşma yapılmıştır. Konuşmalarda Atatürk'e olan saygı ve sevgi, onun gerçekleştirmiş olduğu büyük başarılar, kahramanlıklar ve inkılaplardan bahsedilmiş̧ir. Konuşmalar ant içilerek sonlandırılmıştır. Saat tam 16:00'da ise atılan top atışıyla Atatürk için üç dakikalık saygı duruşu yapılmış, ardından meşaleler yakılmış ve son olarak büstün önünden resmi geçit yapılarak merasime son verilmiştir. ${ }^{51}$

\section{7- Samsun:}

Atatürk'ün aziz hatırasını anmak için Samsunlular saat 11:00'da Halkevi önüne gelmişlerdir. Daha sabahın ilk saatlerinden itibaren havanın yağmurlu olmasına aldırmayan vatandaşlar Halkevi'nin bütün odaları, bahçesi ve etrafinı tıklım tıklım doldurmuş Ankara Radyosu'nun yayınını dinlemeye başlamışlardır. Törene Halkevi bandosunun çaldığı İstiklal Marşı ile başlanılmıştır. Ardından Lise Öğretmeni Emin Hekimgil Atatürk'ün hayatını, başarılarını ve İstiklal Mücadelesi'nde başardığı büyük işleri, inkılapları anlatmıştır. Saat 14:00'da ise Atatürk heykeli önünde yapılan tören için vatandaşlar daha önceden yerlerini almıştır. Kalabalık o kadar fazladır ki, yalnızca heykelin etrafı değil meydanlar, caddeler ve evlerin balkonları dahi dolup taşmıştır. 21 Kasım günü bütün resmî kurumların yanı sıra özel iş yerleri de kapanmış ve herkes Ata'sını anmaya koşmuştur. Tören başlamadan önce birçok kurum Atatürk heykelinin önüne çelenk koymuştur. Akabinde askerî bandonun çaldığı İstiklal Marşı ile tören başlamıştır. Törendeki insanlar çok büyük bir hüzün ve sstırap içerisindeydiler. İstiklal Marşı'nın ardından CHP İl Yönetim Kurulu 
Başkanı Fuat Tuksal kürsüye gelerek bir konuşma yapmışlardır. Akabinde şehir namına Belediye Yazı İşleri Müdürü Rasim Ozantürk, Halkevi adına Ali Ertan, halk adına Fevkiye Bilgiç birer konuşma yapmışlardır. Bu konuşmaların bitiminde öğrenciler Atatürk'ün Gençliğe Hitabesi'ni okumuşlar ve ant içmişlerdir. Saat 16:00'da ise şehrin Saat Kulesi'nden ve Devlet Demiryolları atölyesinden çalınan düdük sesleri ile üç dakikalık saygı duruşu yapılmıştır. Bunu müteakip üç kız, üç erkek öğrenci Atatürk heykeli etrafından altı meşaleyi yakmışlardır. Son olarak geçit yapılmış ve tören bitmiştir. ${ }^{52}$

\section{8- Siirt:}

Siirt'te saat tam 09:00' da vali ve askerî bürokrasi matem töreni için hazır bulunmuşlardır. Ardından saat 10:30'da Atatürk heykeli etrafında vatandaşlar toplanmışlardır. Aynı saatte İstiklal Marşı ile törene başlanmıştır. Akabinde Siirt Valisi kürsüye geçmiş “Ey Türk Milleti Başın Sağolsun” hitabıyla herkesi hüzne boğan bir konuşma yapmıştır. Akabinde kürsüye Türkçe Öğretmeni Tevfik Nalçacı çıkarak bir konuşma da o yapmıştır. Konuşmalara ant içilerek son verilmiştir. ${ }^{53}$

\section{9-Sinop:}

Türk Milleti'nin kurtarıcısı Atatürk için Ankara'da yapılan cenaze töreni günü yurdun her tarafında olduğu gibi Sinop'ta da matem töreni büyük bir kalabalık ve ehemmiyetle yapılmıştır. Bu bağlamda 15.11.938 gün ve 8/1310 sayılı talimat üzerine teşkil edilen komisyon tarafından hazırlanan program itinayla tatbik edilmiştir. Buna göre, sabahın erken saatlerinde Ankara Radyosu'nun yayını vatandaşlar tarafından hüzünlü bir şekilde dinlenmiştir. Saat 14:00'da şehir parkında sivil-askerî bürokrasi, öğrenciler, memurlar ve vatandaşlar daha önceden belirlenen yerlerini almışlardır. Tören İstiklal Marşı'nın okunması ile başlamıştır. Ardından konuşmacılar tarafından Ata'nın milletine ve memleketine yaptığı sayısız hizmetlerden bahsedilmiştir. Daha sonra Atatürk büstünün önüne çelenkler koyulmuş ve üç dakikalık saygı duruşuna geçilmiştir. Ardından büstün etrafındaki altı meşale yakılmıştır. Son olarak saygı geçidi yapıldıktan sonra saat 16:00'da törene son verilmiştir. Tören vilayet merkezinde olduğu gibi Sinop'un ilçe ve köylerinde de benzer şekilde büyük bir kalabalığın katılımıyla yapılmıştır. ${ }^{54}$

\section{0- Tokat/Turhal:}

Tören başlamadan önce Atatürk'ün büstü Turhal Cumhuriyet Meydanı'na yerleştirilmiştir. Ayrıca bir kargaşanın önüne geçebilmek amacıyla törene katılacakların ne şekilde yer alacağı ayrıntılı şekilde belirlenmiştir. Bu esnada Şeker Fabrikası'ndan alınan hoparlörler vasıtasıyla vatandaşların Ankara Radyosu'nun yayını takip etmesi sağlanmıştır. Saat 14:00'da herkes yerlerini almış ve İstiklal Marşı ile tören başlamıştır. İlk olarak çelenkler büstün önüne konmuş akabinde konuşmacılar Atatürk'ün aziz hatırası için nutuklarını okumuşlardır. Saat 16:00'da atılan top atışıyla üç dakikalık saygı duruşu gerçekleştirilmiştir. Sonrasında şehrin önde gelenleri ve vatandaşların katılımıyla büstün önünden geçit resmi yapıldıktan sonra törene son verilmiştir. ${ }^{55}$

\section{1- Van:}

Van'da 21 Kasım günü bütün kurumlar ve özel iş yerleri kapatılmıştır. Ayrıca halk Ata'sına veda edebilmek için sabahın erken saatlerinde Halkevi önünde toplanmaya başlamıştır. İstiklal Marşı ile başlayan tören Halkevi üyelerinden Yakup Kuşçuoğlu’nun Türk Milleti’nin kurtarıcısı,

52 BCA, 490.1.0.0.1432.734.1, Lef 96.

53 BCA, 490.1.0.0.1432.734.1, Lef 56.

54 BCA, 490.1.0.0.1432.734.1, Lef 1-2.

55 BCA, 490.1.0.0.1432.735.1, Lef 88-91. 
kurucusu Atatürk için duyulan derin acıyı anlatan bir konuşma yapmıştır. Ardından Atatürk'ün başardığı zorlu işleri ve büyük inkılapları Van halkına bir kez daha anlatmıştır. Halkevi'ndeki konuşmalar sona erdikten sonra törenin yapılacağı Van Cumhuriyet Meydanı alanındaki Atatürk büstü bayraklarla sarılmıştır. Vatandaşlar meydanı erkenden doldurmuşlardır. Saat 13:30'da Halkevi, Belediye, Çocuk Esirgeme Kurumu, okullar, Hava Kurumu ve esnaflar çelenklerini Atatürk büstünün önüne yerleştirmişlerdir. Saat 13:57' de tören vaziyeti almış binlerce kişi Atatürk büstünde yarıya indirilmiş Türk bayrağı önünde elem içinde beklemeye geçmiştir. Saat 14:00' da bandonun İstiklal Marşı'nı çalması ile tören başlamıştır. Ardından Öğretmenler Sırrı Akatay, İbrahim Özkan ve Yakup Kuşçuoğlu birer konuşma yapmışlardır. Konuşmaların ardından Atatürk'ün inkılaplarının korunacağına dair ant içilmiştir. Saat 16:00'da çalınan düdüklerin ardından üç dakikalık saygı duruşu yapılmıştır. Daha sonra büstün önündeki altı meşale ateşlenmiştir. Geçit resminin ardından törene son verilmiştir. Tören Van’ın kaza ve köylerinde de aynı kalabalık ve elem içerisinde gerçekleştirilmiştir. ${ }^{56}$

\section{2- Yozgat:}

Ebediyete intikal eden Atatürk için matem töreni tüm yurtta olduğu gibi Yozgat ilinde de büyük bir hüzün içerisinde geçmiştir. 21 Kasım Pazartesi günü daha sabahtan itibaren hafif çiseleyen yağmura rağmen bütün şehir halkı caddeleri, hoparlör koyulmuş meydanları doldurmuştur. Ankara'da başlayan büyük merasimin ayrıntısını takip edebilmek için yağmurun artmasına inat halk kalabalığı da giderek artmıştır. Saat 11:00'da Halkevinin büyük salonu, salona açılan odalar hıncahınç dolmuştur. Halkevi’ndeki törene İstiklal Marşı ile başlanmıştır. Akabinde Atatürk'ün biyografisi Lise Müdürü Şinasi Bey tarafından halka okunmuştur. Ardından kürsüye geçen Mücteba Öğretmen Atatürk'ün Gençliğe Hitabesi'ni okumuştur. Konuşmaların ardından üç dakikalık saygı duruşu yapılmış ve Halkevi'ndeki törene 12.30'da son verilmiştir. Yağmur bu esnada bir parça azalmıştır. Sokaklar, caddeler merasime daha saatler olmasına rağmen çok kalabalıklaşmıştır. Kadın, çocuk, yaşlı demeden bütün millet Ata'sını uğurlamak için meydanlara inmiştir. Saat 14'te sivil-asker herkes yerlerini alıp törene hazır hale gelmişlerdir. Bu esnada çelenkler meşaleler ile çevrili Atatürk büstü önüne koyulmuştur. Saat 15'te İstiklal Marşı çalınmış ardından konuşmacılar kürsüye geçip nutuklarına başlamışlardır. İlk konuşmacı CHP adına Vali Feyzi Gürel'dir. Gürel, "Ağlayan bir vatanın, ağlayan yarın ve ağyarın göz yaşlarından örülmüş hâlesi içinde büyük Atatürk'ün her yönde büyüklügünü tebarüz ettirdi... ” sözleriyle konuşmasına başlamıştır. Akabinde vilayet öğretmenlerinden bazıları kürsüye çıkıp birer konuşma yapmışlardır. Konuşmaların içeriği hep hüzün ve keder doludur. Saatler 16:00’1 gösterdiği vakit elektrik fabrikasının düdüğü duyulmuş ve herkes şapkalar elde, başlar öne eğik bir şekilde üç dakika saygı duruşuna geçmiştir. Ardından bütün halk büstün önünden geçip Ata'sına son görevini yerine getirmenin gururunu yaşamış ve törene son verilmiştir. ${ }^{57}$

\section{Sonuç}

Atatürk'ün ölümü Türk halkını derinden üzmüş ve gerek yurt dışında gerekse de ülke içinde büyük yankı uyandırmıştır. Türk Milleti beklenmeyen bu vefat karşısında memleketin her yanında matem merasimleri düzenlemiştir. CHP Genel Merkezi'nin ve Hükümet'in göndermiş olduğu talimatlar doğrultusunda belirlenen matem törenleri ülkenin hemen her yerinde ufak farklılıkların haricinde benzer şekillerde yapılmıştır. Matem törenlerindeki farklılıklar daha çok yapılan konuşmalarda kendini göstermiştir. Ayrıca törenler birçok vilayette imkanlar dahilinde fotoğraflanmıştır. Törenler çocuk, yaşlı demeden her yaştan insanın büyük katımıyla gerçekleşmiştir.

56 BCA, 490.1.0.0.1432.735.1, Lef, 4-6.

57 BCA, 490.1.0.0.1432.735.1, Lef 2-3. 
Ortak dil hüzün ve O’nu kaybetmenin verdiği acı olmuştur. Törenlere en çok sahip çıkan kitle hiç şüphesiz Atatürk'ün Cumhuriyet'i emanet ettiği gençlik olmuştur. Gençler tören boyunca hep en önde olmuş ve Ata'sına son görevini layıkıyla yerine getirmiştir. Vilayetlerde gerçekleştirilen matem törenlerinin neredeyse Ankara'daki kadar kalabalık ve başarılı bir şekilde organize edildiği görülmüştür. Ülkenin hiçbir yerinde merasim esnasında herhangi bir problemle karşılaşılmamıştır. Kısacası ömrünü ülkesine ve milletine adamış olan Atatürk'ün vefatından sonra yapılan matem törenlerindeki katılımın yüksekliği Türk Milleti ile Ata’sının arasında çok güçlü bir bağ olduğunu ve Türk Milleti'nin Atatürk'ü ne kadar çok sevdiğini bir kez daha kanıtlamıştır.

\section{Kaynakça \\ Arşiv Kaynakları \\ $\mathrm{BCA}^{58}$ \\ Süreli Yayınlar \\ Akşam \\ Anadolu \\ Aydın \\ Cumhuriyet \\ Son Posta \\ Tan \\ Ulus}

\section{Araştırma Eserleri}

Akseki, Cengiz (2016), “Atatürk'ün Ölümünün Türk Ulusal Basınına Yansıması (1938-1939)”, $B E L G \dot{I}, 12$, s. 202-236.

Aydın, Nermin Zahide (2019), "Mustafa Kemal Atatürk'ün Ölümü Üzerine Kilis Basınında Yer Alan Haberler", Muallim Rlfat Eğitim Fakültesi Dergisi, 1/1, s. 68-79.

Boran, Tunç (2011) “Atatürk'ün Cenaze Töreni: Yas ve Metanet”, Ankara Üniversitesi Türk İnkllâp Tarihi Enstitüsü Atatürk Yolu Dergisi, 7, s. 487-520.

Çakır, İbrahim, (2007) Atatürk'ün Ölümünün Türk Basınındaki Yankıları, Niğde Sosyal Bilimler Enstitüsü (Yayınlanmamış Yüksek Lisans Tezi), Niğde, s. 58-59.

Çalık, Ramazan (2002), “Atatürk’ün Vefatı ve Alman Basını”, 18/54, Atatürk Araştırma Merkezi Dergisi, s. 875-902.

Güher, Ebru (2018), “Başbakanlık Cumhuriyet Arşivi Belgelerinde Mustafa Kemal Atatürk'ün Vefatının Kamuoyuna Yansımaları”, Akademik Tarih ve Düşünce Dergisi, 5/18, s. 93-120.

Haykır, Yavuz (2014), “Atatürk’ün Ölümü Dolayısıyla Elazı̆̆’da Yapılan Matem Töreni”, Turkish Studies, 9/4, s. 529-562.

Kodal, Tahir (1999), “Atatürk’ün Ölümü ve Denizli Kamuoyu”, PAÜ Eğitim Fakültesi Dergisi, 5, s. 17-26.

Üçüncü, Uğur (2013), “Atatürk'ün Ölümü ve Cenaze Törenlerinin Türkiye'deki Yansımaları”, JASSS, 6/7, s. 1185-1215.

Üçüncü, Uğur (2013), “Atatürk'ün Cenaze Merasimi Sırasında Türkiye'de Yapılan Matem Törenleri”, Türk Dünyasi Incelemeleri Dergisi, 8/1, s. 79-103.

Özbil, Alev (2012), “Türkiye Cumhurbaşkanlarının Cenaze Merasimleri”, Yakın Dönem Türkiye Araştırmalart, 11/22, s. 23-61.

Uzun, Hakan (2009), “Liderine Ağlayan Bir Ulus: Atatürk'ün Ankara'daki Cenaze Töreni”, Ankara Üniversitesi Türk Inkllâp Tarihi Enstitüsü Atatürk Yolu Dergisi, 43, s. 531-553.

$58{ }^{*}$ Cumhuriyet Arşivi fon kodları metin içerisinde verilmiştir. 
Tarih ve Gelecek Dergisi, Eylül 2020, Cilt 6, Say 3

1064 Journal of History and Future, September 2020, Volume 6, Issue 3

\section{Ekler}

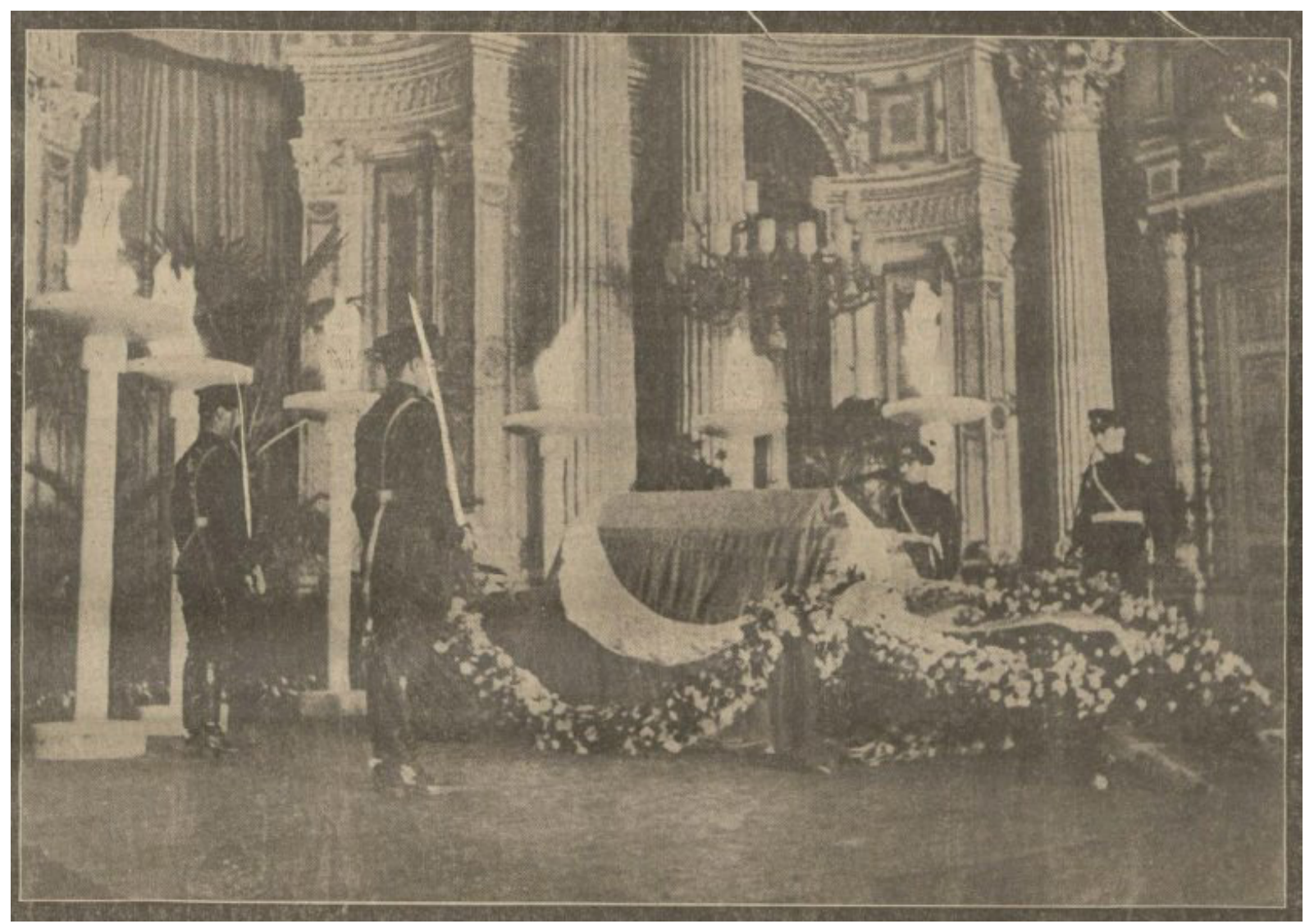

Ek 1: İstanbul halkının Atatürk’ün naaşını Dolmabahçe Sarayında ziyareti esnasında (Akşam, 16 Kasim 1938, nr. 7216, s. 1). 


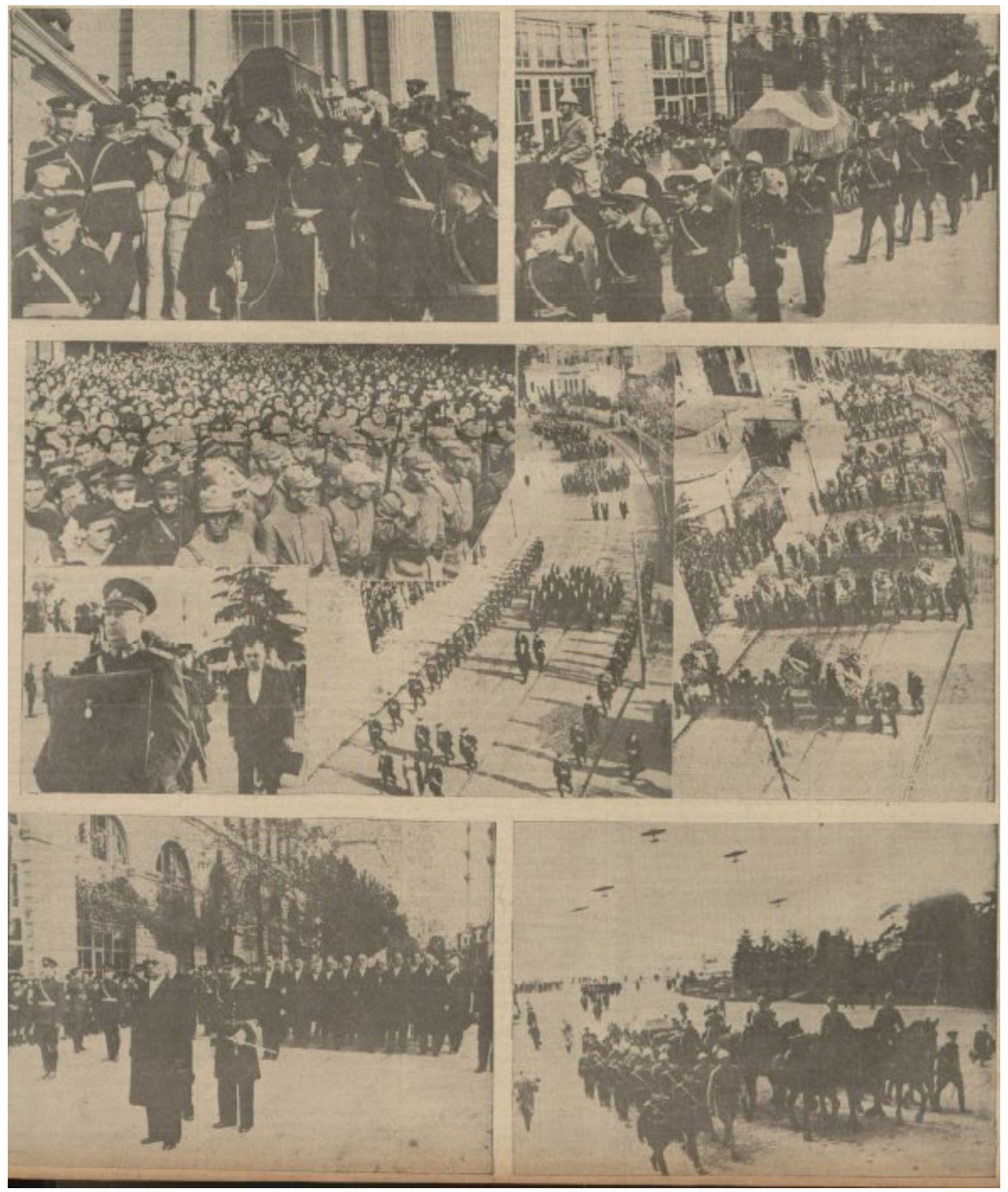

Ek 2: Atatürk’ün Naaşının Ankara’ya nakli (Akşam, 19 Kasım 1938, nr. 7219, s. 1). 


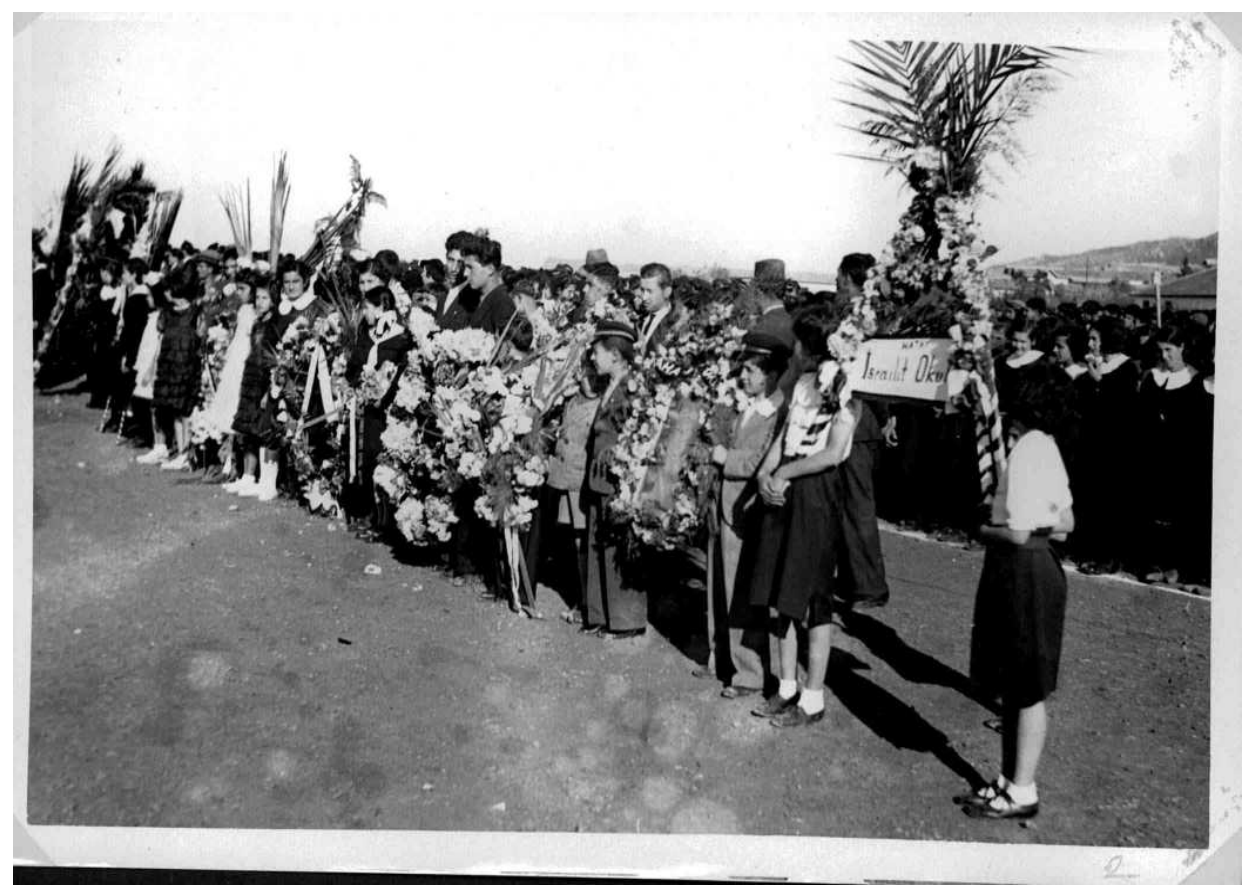

Ek 3: Bolu' da düzenlenen matem töreninden bir kesit (BCA, 490.1.0.0.1429.725.1).

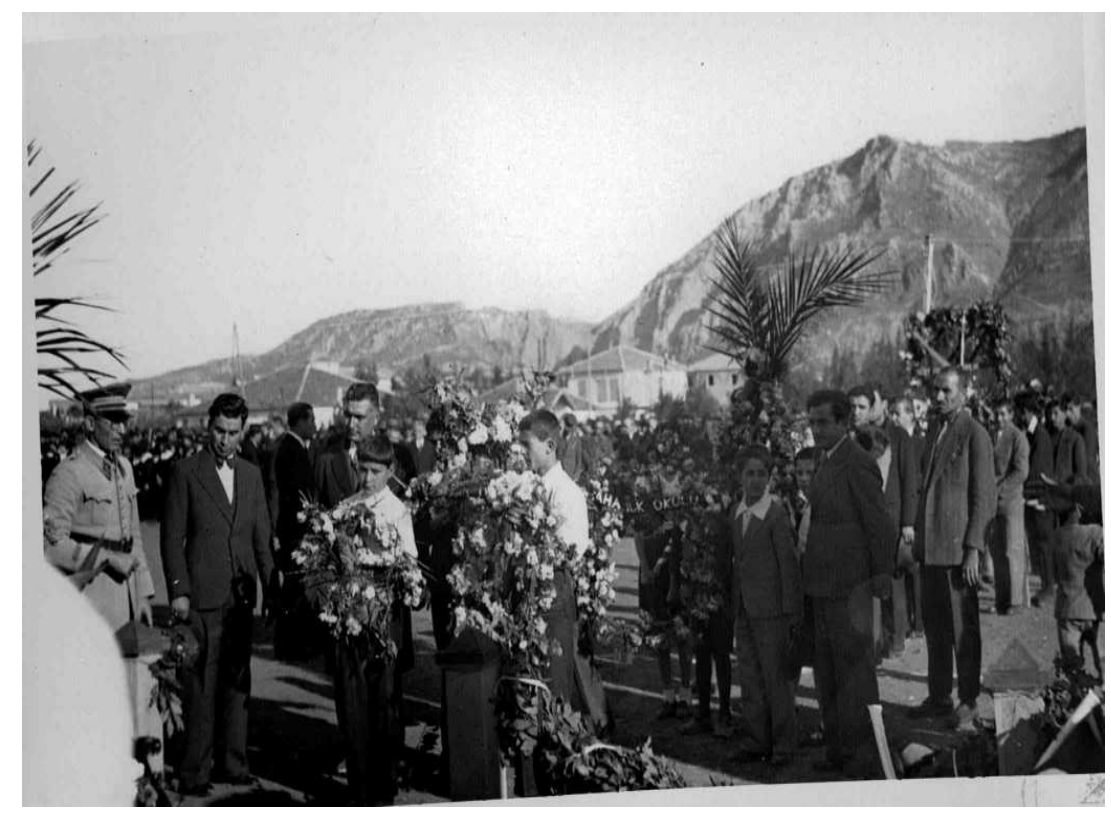

Ek 4: Çocukların Atatürk büstüne çiçek koyduğu an (BCA, 490.1.0.0.1429.725.1). 


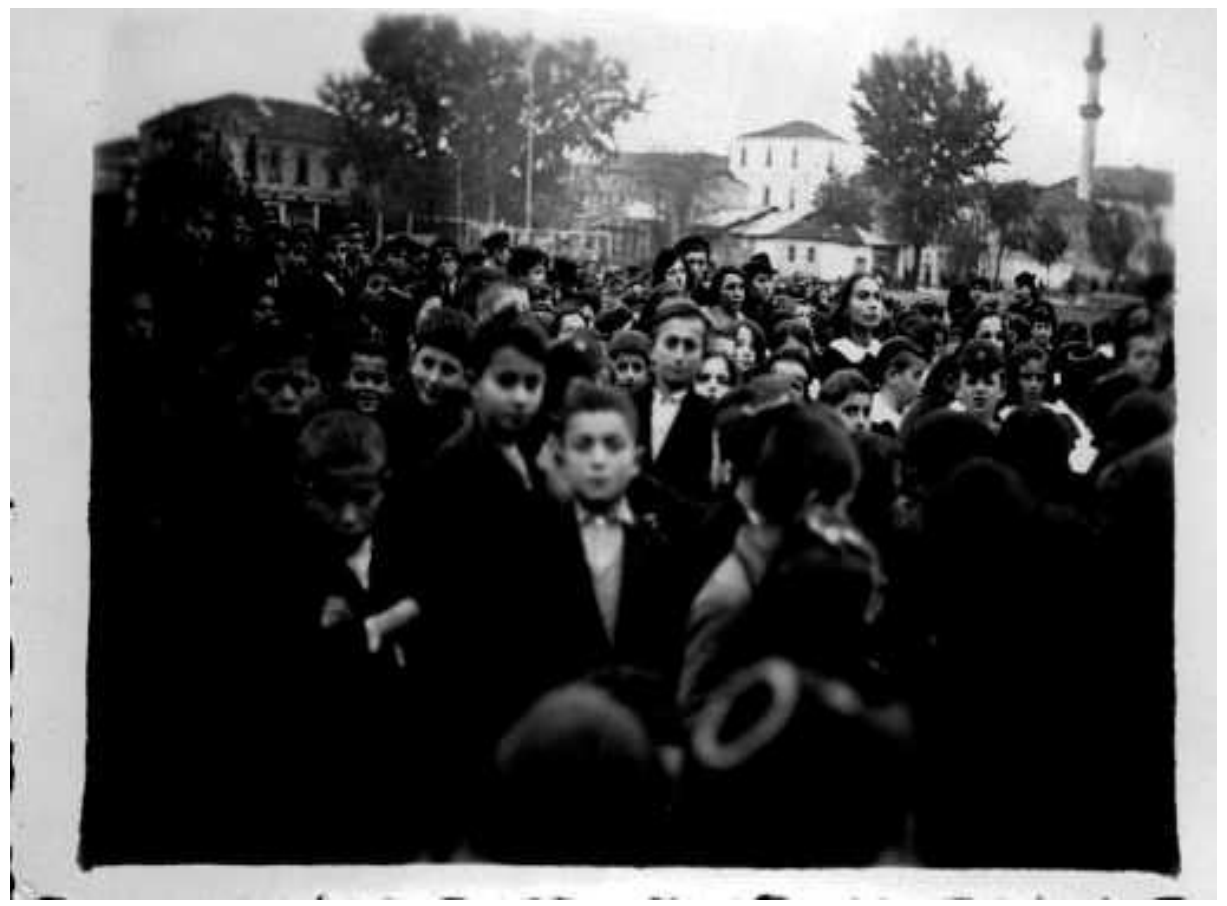

Ek 5- Ordu'daki matem töreninden bir kesit (BCA, 490.1.0.0.1432.733.1).

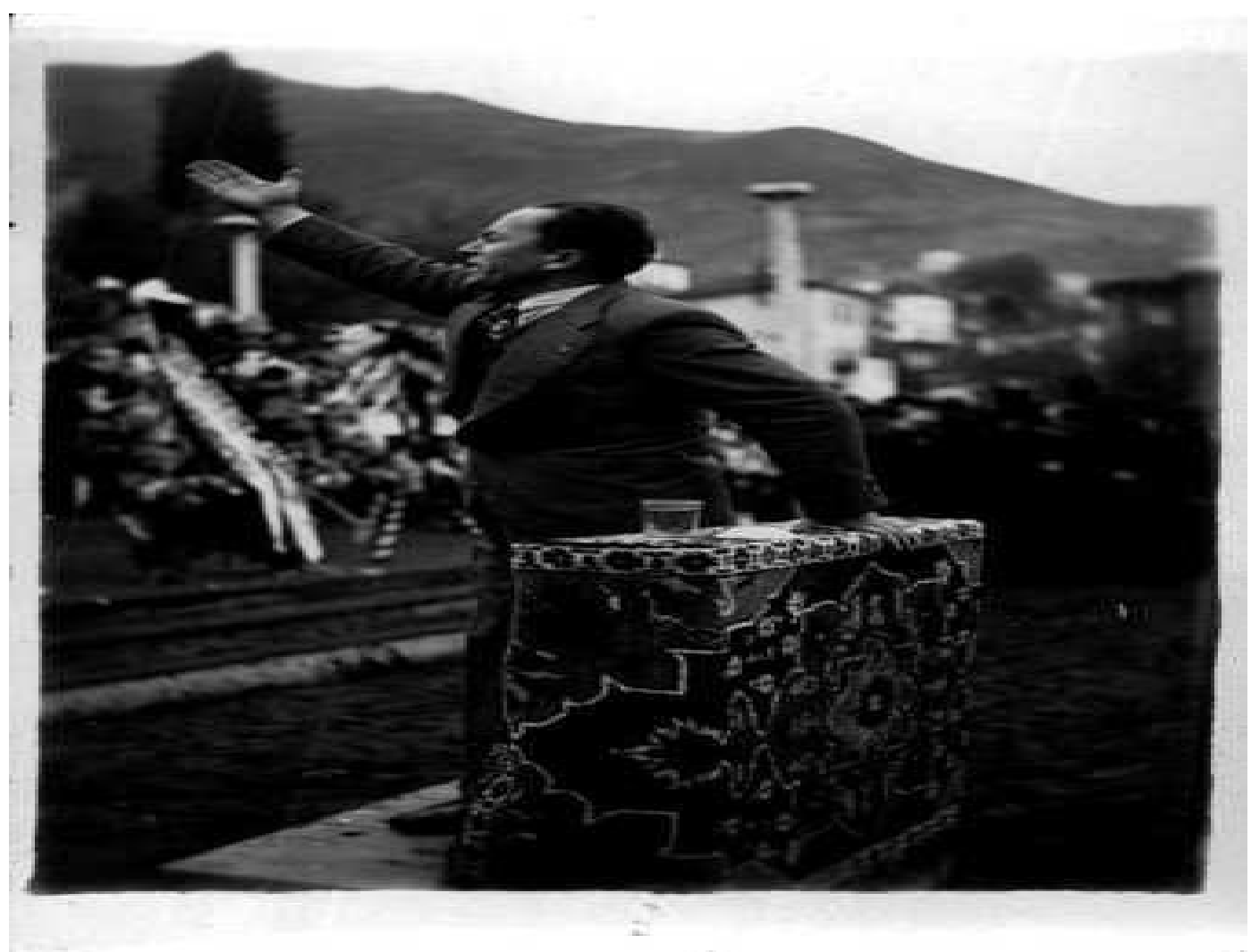

Ek 6: Atatürk için yapılan konuşmadan bir kare (BCA, 490.1.0.0.1432.733.1). 


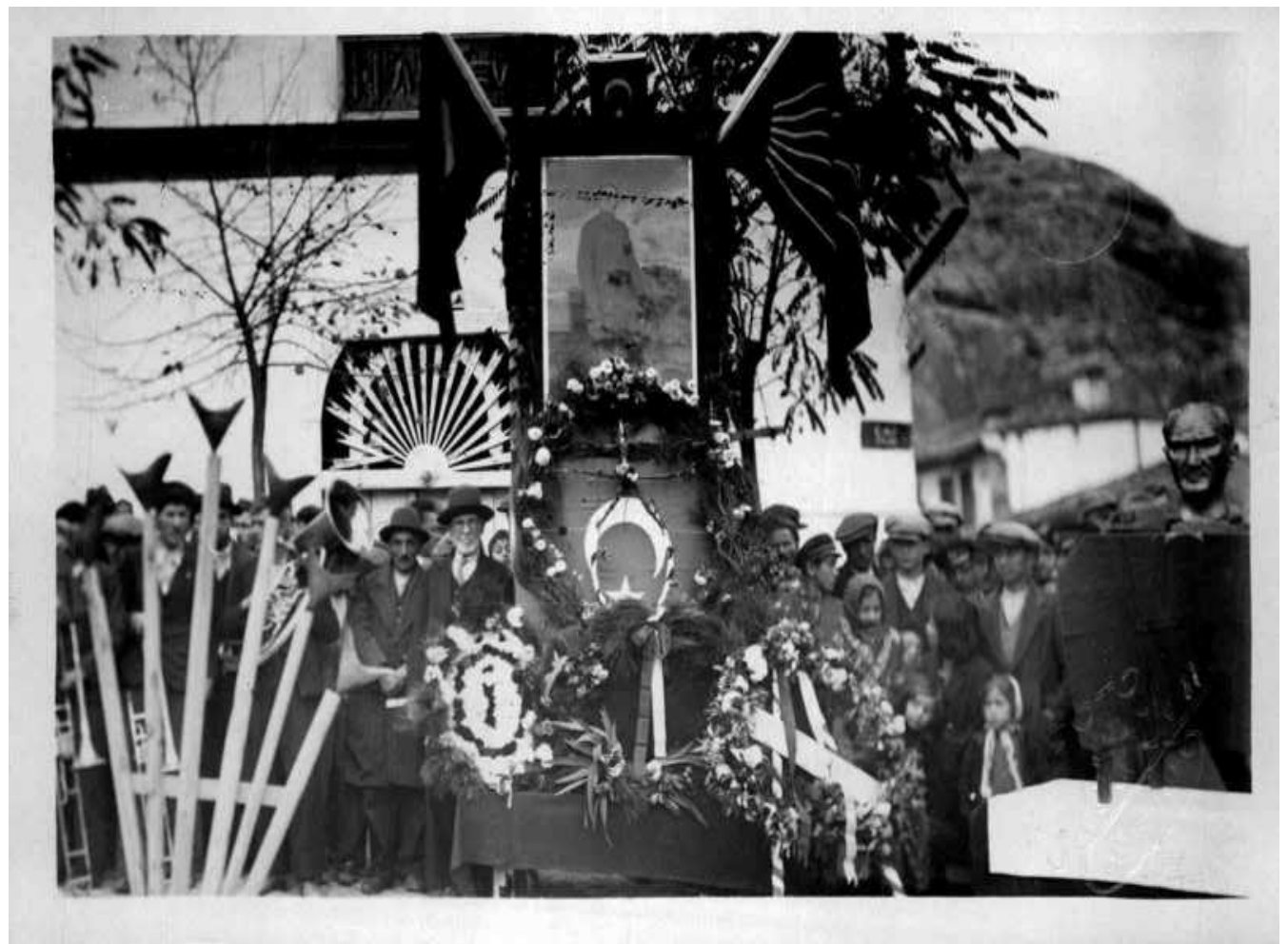

Ek 7: Sinop'ta Türk Milleti Ata'sını saygı ile anarken (BCA, 490.1.0.0.1432.734.1).

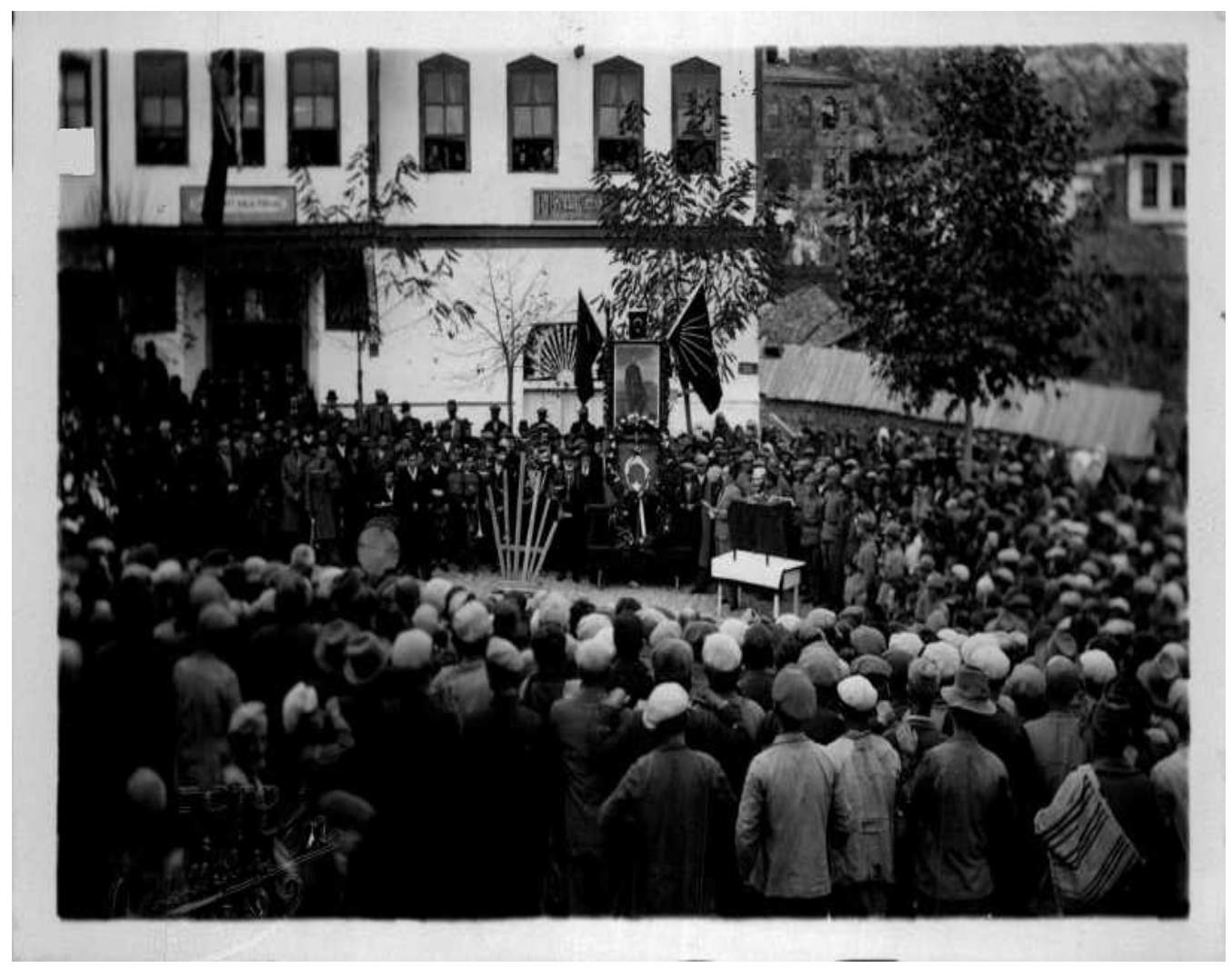

Ek 8: Sinop’ta meydanlar Atatürk için doldu (BCA, 490.1.0.0.1432.734.1). 